\title{
PERAN IBU MENYUSUI YANG BEKERJA DALAM PEMBERIAN ASI EKSKLUSIF BAGI BAYINYA
}

\author{
Nurlaili Susanti \\ Jurusan Biologi Fakultas Sains dan Teknologi UIN Maliki Malang \\ email :dr.santie@gmail.com
}

\begin{abstract}
Exclusive breastfeeding is defined as an infant's consumption of human milk without complementary foods for the first six months of life. Breastfeeding has many benefits and advantages for infants. Breast milk suffice infant's necessary for energy, protein, vitamin and mineral. In addition, breast milk protect infants from susceptibility to infectious disease. Increased vulnerability to nutritional problems in infants recently due to the replacement of breast milk with formula milk in a manner and amount that can not satisfy infant's need. Many problems were encountered in efforts to provide exclusive breastfeeding, one of which is the number of breastfeeding mothers who must return to work after the leave ends. Therefore, mothers need knowledge and skill to provide exclusively breastfeeding on their infants during work.
\end{abstract}

Air Susu Ibu (ASI) Eksklusif adalah pemberian ASI tanpa makanan pendamping sampai bayi berusia 6 bulan. ASI memiliki banyak sekali manfaat dan keunggulan bagi bayi. ASI memenuhi kebutuhan sumber energi, protein, vitamin dan mineral utama bagi bayi. Selain itu, ASI memiliki kandungan yang menjaga bayi dari kerentanan terhadap penyakit infeksi. Meningkatnya masalah kerawanan gizi pada bayi akhir-akhir ini, salah satunya disebabkan penggantian ASI dengan susu formula, dengan cara dan jumlah yang tidak dapat memenuhi kebutuhan bayi. Beberapa kendala yang muncul dalam upaya pemberian ASI eksklusifini, diantaranya adalah banyaknya ibu menyusui yang harus kembali bekerja setelah masa cuti berakhir. Oleh karena itu, dibutuhkan pengetahuan dan keterampilan bagi ibu agar dapat memberikan ASI eksklusif pada bayi selama ditinggal bekerja.

Keywords : ASI eksklusif, ibu menyusui, bayi, bekerja. 


\section{Pendahuluan}

Air Susu Ibu (ASI) Eksklusif adalah pemberian ASI saja pada bayi dari ibu, tanpa tambahan makanan padat atau cair lainnya kecuali sirup atau obat tetes yang mengandung suplemen vitamin, mineral, atau obat (Labbok, 2000). WHO (World Health Organization) merekomendasikan pada ibu di seluruh dunia untuk menyusui secara eksklusif pada bayinya dalam 6 bulan pertama setelah lahir untuk mencapai pertumbuhan yang optimal, perkembangan dan kesehatan (WHO, 2011).

ASI memiliki banyak sekali manfaat bagi bayi. Pemberian ASI yang optimal merupakan kegiatan penting dalam pemeliharaan anak dan persiapan generasi penerus yang berkualitas di masa depan. Pertumbuhan dan perkembangan bayi dipengaruhi oleh jumlah nutrisi yang dikonsumsi. Kebutuhan nutrisi ini sebagian besar dapat terpenuhi dengan pemberian ASI yang cukup. ASI tidak hanya sebagai sumber energi utama tapi juga sebagai sumber protein, vitamin dan mineral utama bagi bayi (Richard et all, 2003). Terjadinya kerawanan gizi pada bayi disebabkan makanan yang kurang serta penggantian ASI dengan susu botol dengan cara dan jumlah yang tidak memenuhi kebutuhan (Siregar, 2004)

Ibu yang melahirkan mampu menghasilkan air susu dalam jumlah yang cukup untuk kebutuhan bayinya selama 6 bulan pertama tanpa makanan tambahan berkisar 80\% (Anonymous, 2010). Menurut data Survei Demografi dan Kesehatan (SDKI) tahun 1997 dan 2002, lebih dari 95\% ibu pernah menyusui bayinya, namun yang menyusui dalam 1 jam pertama cenderung menurun dari $8 \%$ pada tahun 1997 menjadi 3,7\% pada tahun 2002. Cakupan ASI eksklusif 6 bulan menurun dari 42,4\% tahun 1997 menjadi 39,5\% pada tahun 2002. Penggunaan susu formula justru meningkat lebih dari 3 kali lipat selama 5 tahun dari 10,8\% tahun 1997 menjadi 32,5\% tahun 2002 (Handayani, 2010).

ASI eksklusif selama 6 bulan merupakan makanan terbaik bagi bayi, akan tetapi dalam pelaksanaannya banyak kendala yang muncul, antara lain ibu kurang memahami tata laksana laktasi yang benar, produksi ASI kurang, bayi terlanjur mendapatkan prelacteal feeding (air gula atau formula) pada hari pertama kelahiran, kelainan puting ibu, kesulitan bayi dalam menghisap, ibu hamil lagi saat masih menyusui, ibu bekerja sehingga harus meninggalkan bayinya di rumah, keinginan untuk disebut 
modern, dan pengaruh iklan susu formula yang kian gencar (Partiwi, 2009). Kendala tersebut diatas, yang paling sering membuat seorang ibu berpindah ke susu formula adalah alasan pekerjaan. Ibu yang bekerja di sektor publik harus meninggalkan bayinya dalam kurun waktu tertentu, sehingga tidak memungkinkan terjadinya kontak antara ibu dan bayi selama bekerja. Sebenarnya, alasan ini bukanlah kendala yang berarti untuk memberikan ASI eksklusif pada bayi, jika ibu memahami segudang manfaat ASI, memiliki komitmen yang kuat untuk tetap memberikan ASI, dan mengetahui alternatif cara yang bisa ditempuh agar dapat tetap memberikan ASI eksklusif bagi bayinya. Tulisan ini akan mengulas lebih jauh tentang manfaat ASI dan bagaimana metode yang bisa ditempuh oleh ibu bekerja agar tetap dapat memberikan ASI eksklusif bagi bayinya.

\section{Komposisi Air Susu Ibu (ASI)}

Setiap mamalia telah dianugerahi payudara yang akan memproduksi air susu untuk makanan bayi yang baru dilahirkannya. Air susu setiap jenis mamalia berbeda sesuai dengan kebutuhan dan perbedaan laju pertumbuhan bayi. Komposisi air susu ibu berbeda dengan komposisi air susu sapi karena laju pertumbuhan bayi manusia berbeda dengan bayi sapi seperti yang dituliskan pada Tabel 1. Bayi manusia mencapai berat badan dua kali berat badan lahir dalam waktu 4-5 bulan, sedangkan anak sapi hanya membutuhkan waktu 6 minggu untuk ini (Boedihartono, 2002).

Tabel 3. Komposisi Air Susu Ibu dibandingkan Air Susu Sapi (Boedihartono, 2002)

\begin{tabular}{|l|c|c|c|c|}
\hline \multirow{2}{*}{\multicolumn{1}{|c|}{ Komposisi }} & \multicolumn{3}{|c|}{ ASI } & \multirow{2}{*}{ Susu sapi } \\
\cline { 2 - 4 } & kolostrum & $\begin{array}{c}\text { ASI } \\
\text { transisi }\end{array}$ & $\begin{array}{c}\text { ASI } \\
\text { matur }\end{array}$ & \\
\hline Protein (g \%) & 4,1 & 1,6 & 1,2 & 3,3 \\
Lemak (g \%) & 2,9 & 3,5 & 3,7 & 4,3 \\
Laktosa (g \%) & 3,5 & 6,4 & 7 & 1,8 \\
Kalori (kcal/100ml) & 57 & 63 & 65 & 65 \\
Natrium (g \%) & 48 & 29 & 15 & 58 \\
Kalium (g \%) & 74 & 64 & 57 & 145 \\
Kalsium (g \%) & 39 & 46 & 35 & 130 \\
Fosfor (mg \%) & 14 & 20 & 15 & 120 \\
\hline
\end{tabular}


Air susu yang dihasilkan oleh ibu yang melahirkan kurang bulan (ASI prematur) juga berbeda komposisinya dari ASI yang dihasilkan oleh ibu yang melahirkan cukup bulan (ASI matur). Komposisi ASI yang keluar pada hari pertama sampai hari ke 4-7 (kolostrum) juga berbeda dengan ASI yang keluar pada hari ke 4-7 sampai hari ke 10-14 (ASI transisi) dan selanjutnya (ASI matur), seperti yang dituliskan pada Tabel 2 (Boedihartono, 2002).

Tabel 4. Komposisi ASI prematur dibandingkan ASI matur (Boedihartono, 2002)

\begin{tabular}{|l|c|c|c|}
\hline \multirow{2}{*}{\multicolumn{1}{|c|}{ Komposisi }} & \multirow{2}{*}{ ASI matur } & \multicolumn{2}{|c|}{ ASI prematur } \\
\cline { 3 - 4 } & & 1 minggu & 4 minggu \\
\hline Energi (kcal) & 700 & 670 & 700 \\
Protein (g) & 13 & 24 & 18 \\
Karbohidrat (g) & 70 & 61 & 70 \\
Lemak (g) & 42 & 38 & 40 \\
Natrium (mmol) & 6,5 & 22 & 13 \\
Kalium (mmol) & 1,3 & 18 & 16 \\
Calsium (mmol) & 8,7 & 6,2 & 6,4 \\
Fosfor (mmol) & 4,8 & 4,6 & 4,6 \\
Rasio Ca:P & 1,8 & 1,4 & 1,2 \\
\hline
\end{tabular}

\section{Manfaat Air Susu Ibu (ASI)}

ASI memiliki banyak manfaat dan keunggulan baik bagi ibu maupun bayi. Manfaat ASI bagi bayi dapat dilihat dari aspek gizi, aspek protektif dan aspek psikologis, yang dijelaskan sebagai berikut :

\section{Aspek gizi.}

ASI mengandung zat gizi berkualitas tinggi yang sesuai untuk pertumbuhan dan perkembangan kecerdasan bayi ASI. ASI juga mudah dicerna karena mengandung enzim-enzim untuk mencernakan zat-zat gizi yang terdapat dalam ASI tersebut (Boedihartono, 2002). Kandungan zat gizi dalam ASI antara lain :

- Lemak

Lemak merupakan sumber kalori utama dalam ASI. Kadar lemak dalam ASI berkisar antara 3,5-4,5\%. Lemak dalam ASI mudah diserap oleh bayi karena trigliserida terlebih dulu dipecah menjadi 
asam lemak dan gliserol oleh enzim lipase yang terdapat dalam ASI. Kadar kolesterol dalam ASI juga lebih tinggi dari susu sapi karena dibutuhkan untuk merangsang pembentukan enzim protektif, sehingga metabolisme kolesterol menjadi efisien pada usia dewasa.

- Karbohidrat

Karbohidrat utama dalam ASI adalah laktosa. Kadar laktosa ASI lebih tinggi dibanding susu sapi yaitu $7 \mathrm{~g} \%$. Laktosa mudah terurai menjadi glukosa dan galaktosa. Enzim laktase yang diperlukan untuk metabolisme terdapat dalam mukosa bayi sejak lahir. Laktosa dapat meningkatkan penyerapan kalsium dan merangsang pertumbuhan Lactobacillus bifidus.

- Protein

Protein dalam ASI adalah kasein dan air dadih (whey). Kadar protein dalam ASI adalah 0,9\%, dengan perbandingan antara air dadih dan kasein yang sesuai untuk bayi yaitu 65:35. Rasio air dadih yang lebih tinggi dari kasein merupakan salah satu keunggulan ASI dibandingkan dengan susu sapi karena menjadikan protein ASI lebih mudah diserap dibandingkan susu sapi yang mempunyai rasio air dadih dan kasein $20: 80$. Selain itu terdapat 2 asam amino dalam ASI yang tidak terdapat dalam susu sapi yaitu sistin dan taurin. Sistin diperlukan untuk pertumbuhan somatik sedangkan taurine diperlukan untuk pertumbuhan otak.

- Garam dan mineral

Kadar garam dan mineral dalam ASI lebih rendah dari susu sapi. Ini dibutuhkan karena ginjal bayi belum dapat mengkonsentrasi urine dengan baik. Bayi yang minum susu formula tanpa modifikasi meskipun kadar kalsium dan magnesiumnya lebih tinggi, sering menderita tetani akibat kadar fosfor dalam susu sapi jauh lebih tinggi, sehingga mengganggu penyerapan kalsium dan magnesium. Zat besi dalam ASI kadarnya sedikit tapi mudah diserap. Jumlah ini ditambah dengan cadangan besi saat lahir cukup untuk memenuhi kebutuhan besi sampai umur 6 bulan. 
- Vitamin

ASI mengandung vitamin yang dibutuhkan oleh bayi, diantaranya vitamin $\mathrm{K}$ dan $\mathrm{E}$.

- Taurin, DHA dan AA

Taurin adalah sejenis asam amino kedua yang terbanyak dalam ASI yang berfungsi sebagai neurotransmiter dan berperan penting untuk proses maturasi sel otak. Docosahexanoic Acid (DHA) dan Arachidonic Acid (AA) adalah asam lemak tak jenuh rantai panjang (polyunsaturated fatty acids), yang diperlukan untuk pembentukan sel-sel otak yang optimal. Jumlah DHA dan AA dalam ASI sangat mencukupi untuk menjamin pertumbuhan dan kecerdasan anak.

- Kolostrum

Kolostrum adalah ASI yang keluar pada hari pertama sampai hari ke 4-7 yang mengandung protein dan vitamin A yang tinggi serta karbohidrat dan lemak rendah, sehingga sesuai dengan kebutuhan gizi bayi pada hari-hari pertama kelahiran. Kolostrum harus diberikan pada bayi, meskipun jumlahnya sedikit tapi cukup untuk memenuhi kebutuhan gizi bayi dan membantu mengeluarkan mekonium.

\section{Aspek protektif}

Bayi yang mendapat ASI akan lebih jarang menderita sakit dibandingkan bayi yang tidak mendapat ASI (Boedihartono, 2002). Hal ini dikarenakan ASI mengandung zat protektif yang dapat melindungi bayi dari infeksi bakteri, virus, dan jamur, antara lain :

- Faktor bifidus

Lactobacillus bifidus cepat tumbuh dan berkembang biak dalam saluran pencernaan bayi yang mendapat ASI, karena ASI mengandung polisakarida yang berikatan nitrogen. Bakteri ini akan mengubah laktosa yang banyak terdapat dalam ASI menjadi asam laktat dan asam asetat, sehingga menjaga keasaman flora usus bayi dan menghambat pertumbuhan bakteri yang merugikan.

- Imunitas humoral

Secretory Immunoglobulin A (sIgA) kadarnya cukup tinggi 
dalam ASI terutama dalam kolostrum. Imunoglobulin ini tahan terhadap enzim proteolitik dalam saluran pencernaan dan membentuk lapisan di permukaan mukosa usus sehingga mencegah masuknya bakteri patogen dan enterovirus.

- Imunitas seluler

Sel darah putih dalam ASI pada 2 minggu pertama berjumlah lebih dari 4000 sel per-mil. Selain itu ASI banyak mengandung makrofag yang berfungsi membunuh dan memfagositosis mikroorganisme, membentuk komplemen C3 dan C4 serta lisozim dan laktoferin.

- Lisozim

Lisozim adalah enzim yang melindungi bayi terhadap bakteri Eschericia coli dan Salmonella sp serta virus. Jumlah lisozim dalam ASI 300 kali lebih banyak daripada susu sapi.

- Laktoferin

Laktoferin adalah protein yang terikat dengan zat besi. Fungsinya menghambat pertumbuhan Staphyilococcus sp. dan Eschericia coli dengan jalan mengikat zat besi sehingga bakteri terhambat pertumbuhannya. Selain itu, laktoferin juga menghambat pertumbuhan jamur Candida sp. (Dirjen Gizi Masyarakat, 2001).

\section{Aspek psikologik}

Pada saat menyusui terjadi interaksi antara ibu dan bayi. Interaksi ini akan merajut ikatan kasih sayang ibu dan bayi akibat berbagai rangsangan seperti sentuhan kulit (skin to skin contact). Bayi akan merasa aman dan puas karena merasakan kehangatan tubuh ibu dan mendengar denyut jantung ibu yang sudah dikenalnya sejak masih dalam kandungan (Boedihartono, 2002). Perasaan ini penting untuk perkembangan psikologi bayi diantaranya mengembangkan dasar kepercayaan (basic sense of trust) dengan mulai mempercayai orang lain yaitu ibu yang mendukung pembentukan kepercayaan pada dirinya sendiri. Selain itu, dengan menghisap payudara, koordinasi saraf menelan, menghisap dan bernafas yang terjadi pada bayi baru lahir dapat lebih sempurna (Hadi, 2005).

Manfaat menyusui bagi ibu juga banyak sekali. Selain aspek psikologi ibu, isapan mulut bayi pada payudara ibu dapat merangsang 
terbentuknya hormon oksitosin oleh kelenjar hipofisis posterior yang dapat meningkatkan produksi ASI dan mempercepat involusi uterus sehingga mengurangi resiko perdarahan setelah proses melahirkan. Menyusui secara eksklusif dapat menunda kesuburan karena kadar hormon yang mempertahankan laktasi dapat menekan ovulasi sehingga dapat digunakan sebagai kontrasepsi alamiah untuk menunda kehamilan. ASI juga sangat praktis, tidak merepotkan, tidak perlu dibeli dan selalu tersedia dengan suhu yang sesuai (Boedihartono, 2002).

\section{Manajemen Laktasi}

Payudara ibu telah dipersiapkan untuk laktasi oleh hormon yang disekresi sejak proses kehamilan. Selama kehamilan, terjadi proliferasi selsel duktus laktiferus dan sel-sel kelenjar air susu akibat pengaruh hormon estrogen, progesteron dan laktogenik plasenta, serta terjadi peningkatan vaskularisasi pada payudara yang menyebabkan perubahan ukuran payudara menjadi lebih besar (Richard et al, 2003).

Setelah persalinan, sekresi air susu ibu segera timbul di bawah pengaruh hormon prolaktin. Semakin sering bayi menyusu akan semakin banyak air susu yang diproduksi, karena isapan mulut bayi saat menyusu akan merangsang hipotalamus yang akan memerintahkan hipofise anterior mengeluarkan hormone prolaktin ke dalam darah (Handayani, 2010). Selain itu isapan mulut bayi juga merangsang hipofise posterior melepaskan hormon oksitosin yang memicu kontraksi sel mioepitel sehingga menyebabkan keluarnya air susu (let down reflex). Menyusui hingga payudara kosong sangat penting untuk mencegah stagnasi payudara yang dapat menyebabkan penuh dan sakit (engorgement). Volume ASI yang dikeluarkan berkisar antara 0,5-1,5 liter/hari bergantung pada kebutuhan bayi, pola pemberian ASI dan status gizi ibu (Boedihartono, 2002).

Upaya untuk menunjang keberhasilan menyusui harus dimulai sejak masa kehamilan, dengan memeriksakan kesehatan secara rutin termasuk payudara, dan menjaga asupan nutrisi. Perawatan payudara dilakukan mulai usia kehamilan 6 bulan. Setelah persalinan, sebaiknya ibu segera menyusui bayinya. Ibu menyusui membutuhkan asupan gizi 1 1 $\frac{1}{2}$ kali lebih banyak dan air 8 gelas/hari, istirahat cukup dan kondisi psikologis yang tenang. 


\section{Peran Ibu Menyusui yang Bekerja dalam Pemberian ASI Eksklusif}

Sekitar 70\% ibu menyusui di Indonesia adalah wanita bekerja. Masa cuti bagi ibu hamil dan menyusui di Indonesia berkisar antara 1-3 bulan. Ibu yang sudah habis masa cuti dan harus kembali bekerja tetap dapat memberikan ASI eksklusif bagi bayi yang disayanginya. Meskipun tidak ada kontak secara langsung dengan bayi saat ditinggal bekerja, kontak secara psikis melalui pemberian ASI tetap dapat dilakukan (Handayani, 2010). Alternatif cara yang bisa ditempuh adalah dengan pemberian ASI perah. Dibutuhkan motivasi yang kuat dan kesabaran ekstra untuk melakukannya. Ibu sebaiknya mulai menabung ASI 1 bulan sebelum kembali bekerja. ASI perah dapat disimpan dan kemudian dapat dipersiapkan untuk diberikan pada bayi tanpa harus berpikir untuk memodifikasinya dengan susu formula (Anonymous, 2010).

Di sela-sela waktu bekerja, ibu bisa memerah ASI setiap 2-3 jam. Memerah ASI dapat dilakukan dengan tangan dan pompa. Pompa yang paling baik dan efektif adalah pompa elektrik, tapi harganya mahal (Handayani, 2010). Pompa ASI manual ada 2 bentuk yaitu piston dan squeeze and bulb. Bentuk piston memiliki beberapa keunggulan yaitu setiap bagian pompa dapat dibersihkan dan tekanannya dapat diatur, sedangkan bentuk squeeze and bulb tidak dapat disterilkan karena bagian bulbnya terbuat dari karet (Anonymous, 2008).

Memerah ASI dengan menggunakan tangan lebih dianjurkan karena lebih sederhana dan efektif. Sebelum diperah, sebaiknya terlebih dahulu payudara dipijat lembut dengan menggunakan 3 jari tengah. Arah pijatan memutar ke tengah dan menyisir dari pangkal menuju puting. Setelah itu cuci kedua tangan dan atur posisi senyaman mungkin. Penampung ASI yang sudah disterilkan diletakkan di bawah payudara yang diperas. Tangan ditempatkan di salah satu payudara, tepatnya di tepi areola. Posisi ibu jari terletak berlawanan dengan jari telunjuk. Tangan ditekan ke arah dada, lalu dengan lembut tekan ibu jari dan telunjuk bersamaan. Pertahankan agar jari tetap di tepi areola, jangan sampai bergeser ke puting. Kemudian diulangi secara teratur untuk memulai aliran susu. Jari diputar secara perlahan di sekeliling payudara agar seluruh saluran susu dapat tertekan. Tindakan yang sama diulangi pada sisi payudara yang lain, dan jika diperlukan, pijat payudara di antara waktu pemerasan. Kemudian diulangi pada payudara 
pertama lagi, dan selanjutnya pada payudara kedua, demikian seterusnya.

ASI harus di simpan dengan baik setelah diperah agar dapat bertahan lama. Di udara terbuka, ASI perah dapat bertahan 6-8 jam, tapi jika ditempatkan di kantong plastik kemudian dimasukkan termos dan diberi es batu, dapat bertahan kurang lebih 24 jam. Bagi ibu yang memerah asi di tempat kerja bisa menempatkan ASI perahnya di cooler box ASI yang sekarang banyak dijual di toko perlengkapan bayi. ASI dapat disimpan di dalam lemari es selama 3 hari sedangkan dalam freezer, ASI beku dapat bertahan selama 3 bulan. ASI perah yang disimpan ini tidak mengalami perubahan kualitas, hanya warna dan bentuknya saja yang mungkin berubah. Akan tetapi ASI perah yang disimpan dalam freezer akan mengalami penurunan jumlah imunoglobulin A akibat suhu yang terlalu dingin (Handayani, 2010).

Ketika akan memberikan pada si kecil,ASI perah harus dihangatkan terlebih dulu. Caranya bisa dengan menyiram botol ASI dengan kran air hangat atau merendam botol berisi ASI dalam mangkuk yang berisi air hangat. Suhu air hangat ini sama dengan suhu air yang biasa digunakan untuk mandi. Lama penghangatan bergantung pada suhu ASI sebelumnya, suhu yang diinginkan setelah penghangatan adalah sesuai dengan suhu tubuh sehingga menyerupai suhu ASI yang dikeluarkan langsung dari payudara ibu. Setelah itu, ASI siap diberikan pada bayi. Cara pemberian ASI perah pada bayi dibawah usia 6 bulan sebaiknya tidak memakai dot tapi menyuapkannya dengan sendok. Ini dilakukan agar bayi tidak mengalami sindroma bingung puting karena menyusu dengan dot lebih mudah untuk mengeluarkan susu dari pada menyusu pada payudara ibu, dimana bayi membutuhkan isapan yang lebih kuat untuk dapat mengeluarkan susu dari payudara ibu.

Bagi ibu yang sudah terlanjur memberikan susu formula pada bayi pun dapat beralih pada ASI saja. Cara ini dinamakan relaktasi. Dimulai dengan menghentikan penggunaan dot dan memberikan susu atau makanan lain dengan gelas atau sendok. Ini dimaksudkan agar bayi lupa pada dot dan mau menetek payudara ibu kembali. Selanjutnya tingkatkan intensitas kontak kulit antara ibu dan bayi agar hormon laktasi terangsang oleh isapan mulut bayi. Bila bayi mau menetek langsung pada payudara ibu, selang Nasogastric tube (NGT) atau pipet diletakkan pada posisi yang 
lebih tinggi dari payudara untuk mengalirkan cairan ASI perah atau susu formula dari wadah ke mulut bayi. Ibu juga dapat minta bantuan orang lain untuk memegang wadah agar cairan berjalan lancar selama melintasi selang atau membantu meneteskan cairan tepat diatas puting. Ini dilakukan agar ketika bayi berada pada posisi menyusui tidak frustrasi dengan jumlah ASI yang masih sedikit karena hanya dimaksudkan untuk memancing produksi ASI oleh rangsangan isapan mulut bayi. Selama masa ini, ibu dapat berkomunikasi dengan bayi tentang proses relaktasi yang harus dilalui bersama. Proses ini membutuhkan waktu dan kesabaran yang tinggi dalam menjalaninya (Anonymous, 2011).

\section{Kesimpulan}

ASI memiliki manfaat yang sangat besar bagi pertumbuhan dan perkembangan bayi yang berkualitas. ASI eksklusif sampai bayi berumur 6 bulan mampu mencukupi kebutuhan nutrisi utama bayi karena ASI mengandung zat gizi berkualitas tinggi, mudah dicerna dan mudah diserap oleh sistem pencernaan bayi. Disamping aspek gizi, ASI juga memiliki keunggulan dari aspek protektif yang melindungi bayi dari infeksi berbagai mikroorganisme dan juga keunggulan dari aspek psikologis yang mendukung perkembangan kejiwaan bayi. Untuk menunjang keberhasilan menyusui, dibutuhkan persiapan semenjak kehamilan, segera setelah melahirkan dan dalam masa menyusui selanjutnya. Ibu yang kembali bekerja pun dapat tetap memberikan ASI eksklusif kepada bayi melalui ASI perah. Cara ini membutuhkan motivasi dan kesabaran untuk menjalankannya. Pemberian ASI yang berkualitas akan mendukung tumbuhnya generasi yang berkualitas dan memberikan perlindungan dan kasih sayang lebih bagi buah hati kita.

\section{DAFTAR PUSTAKA}

Anonymous. 2008. Teknik Menyusui Pada Ibu Bekerja dan Teknik Memerah ASI, (Online) (http://www.creasoft.wordpress.com diakses 3 Juni 2011).

Anonymous. 2010. ASI Ekslusif dan Perkembangan Balita, (Online), (http://www.depkes.go.id/index.php?option=news\&task=viewart icle\&sid=709\&ite $\mathrm{mid}=2$ diakses 1 Juni 2011) 
Anonymous. 2010. Tantangan Menyusui Bagi Ibu Bekerja, (Online) (http:// www.ayahbunda.co.id diakses 3 Juni 2011).

Anonymous. 2011. Relaktasi bagi yang ingin beralih dari susu formula ke ASI, (Online), ( http://aimi-asi.org/2011/05 diakses 3 Juni 2011).

Boedihartono. 2002. Bahan Bacaan Manajemen Laktasi. Jakarta: Yayasan Perinasia.

Dirjen Gizi Masyarakat. 2001. Sumber: Buku Panduan Manajemen Laktasi. Jakarta: Depkes RI.

Handayani, Faras. 2010. ASI Perah, Solusi Buat Ibu Bekerja, (Online) (http://www.menyusui.net diakses 1 Juni 2011).

Hadi. 2005. Beban Ganda Masalah Gizi dan Implikasi terhadap Kebijakan Pembangunan Kesehatan Nasional. Makalah disampaikan dalam pidato Penyuluhan Jabatan Guru Besar FK UGM Yogyakarta, 2005.

Labbok, Miriam. 2000. What is The Definition of Breastfeeding?. Breastfeeding Abstracts. Volume 19, Number 3, pp. 19-21.

Partiwi, Ayu Nyoman dan Purnawati, Jeanne. 2009. Kendala Pemberian ASI eksklusif dan Cara Mengatasinya, (Online), (http://www.idai. or.id/asi.asp diakses 2 Juni 2011).

Richard, Berhman RE, Kliegmen RM, Jenson HB. 2003. Nelson Textbook of Pediatrics 17th edition. Pennsylvania : W B Saunders.

Siregar, A. 2004. Pemberian ASI Ekslusif dan Faktor-faktor yang Mempengaruhinya, (Online), (http://library.usu.ac.id/fkm/fkmarifinsiregar.pdf. Diakses 2 Juni 2011).

WHO. 2011. Exclusive breastfeeding Exclusive breastfeeding for six months best for babies everywhere, (Online) ( http://www.who. int/mediacentre/news/ statements/2011/ breastfeeding20110115/ en/index.html). Diakses tanggal 25 Januari 2012. 